\title{
Research on the Teaching Reform of National Folk Dance in Colleges
}

Juejun Zhang

Lijiang Teachers College, Lijiang Yunnan, 674100,Lijiang, China.

Abstract: National folk dance, as an artistic form that shows the national artistic style and cultural value of my country, is not only a cultural treasure, but also a fusion of modern civilization and art. Therefore, how to enable students to actively inherit the national culture in the process of participating in learning activities has become a key problem for teachers in colleges and universities to solve. This article starts with the artistic value of folk dances, looking for specific ways to promote the reform of folk dance teaching in colleges and universities, hoping to make suggestions for other teachers.

Keywords: Reform Research; Dance Class; Colleges and Universities; National Dance

With the transformation and inheritance of the society, folk dances have exhibited very distinctive artistic values and regional customs, and as a means for people to promote culture and express emotions, they contain rich research value. The implementation of folk dance teaching in colleges and universities not only enables students to participate in classroom learning activities, to enhance personal cultivation and artistic integrity, but also enables students to feel the nationality while exploring the traditional culture, artistic style and national spirit presented in dance The unique charm of culture, and then in the process of mobilizing the enthusiasm of learning, take the initiative to shoulder the responsibility of maintaining national unity and inheriting culture. So how to ensure the orderly development of folk dance teaching activities is the main research problem of this article.

\section{Artistic Value of National Folk Dance}

\subsection{Geographical Value}

my country has a long history and many nationalities. Therefore, folk folk dance refers to a dance with unique national characteristics formed by different nationalities through practice and production under the influence of their own national customs, living habits, religious beliefs and working methods. Therefore, folk dances in different regions can fully demonstrate the customs and customs of different ethnic groups, and at the same time show different regional characteristics, so they have great regional value.

\subsection{Improvisation value}

The production of many folk dances comes from the expression of people's emotions and compliments of life, so although the dance forms of different nationalities are relatively fixed in appearance, many dance performances are mostly improvised, not only the movements are varied but also The dancer's resilience is extremely demanding. Therefore, folk dances often do not restrict performers with a fixed frame, but encourage dancers to integrate their emotional expressions and actual experience with dance movements, so that they can perform dances full of spirituality and artistic value.

\subsection{Story value}

Many ethnic minorities have rich cultural backgrounds, not only their own customs and religious beliefs, but also many heroic stories and ethnic totems. Therefore, the creation of national folk dances will often be carried out with a 
specific storyline, and the content of the story will be expressed with romantic and beautiful movements. In this way, the dance expression combining action and emotion is not only very easy to mobilize the audience's emotions, but also can show its own cultural characteristics.

\subsection{Convergence value}

National folk dances usually do not appear as separate performances, but are presented to the audience in combination with national musical instruments, folk activities and national songs. Under the effect of this complementarity, not only the content of folk dances is greatly enriched, and the expressions of various art forms are combined, but also the audience can feel the rich connotation of national culture.

\section{Specific ways for colleges and universities to promote the teaching reform of folk dance}

\subsection{Carefully select dance teaching materials}

Many colleges and universities do not pay much attention to the selection of national folk dance teaching materials, so that teachers still carry out teaching activities under the guidance of outdated teaching materials when teaching. This not only seriously hinders the improvement of teaching quality, but also affects the enthusiasm of students to participate in classroom knowledge while the teaching content is difficult to coordinate with the evolving background of the times. Teaching materials with excellent content not only enable teachers to better impart knowledge to students, but also help students to dig deeper into the cultural value of different ethnic dances in the process of learning, so as to ensure the quality of learning, Innovate dance through the extension of thinking ability. This requires teachers to be able to combine the teaching needs, through the analysis of the actual teaching situation of the school and the learning needs of students, and plan the content and difficulty of the national folk dance teaching materials in order to promote student learning in the process of establishing high-quality dance classrooms The purpose of efficiency.

\subsection{Improve teaching methods}

Due to the various forms of folk dances, teachers still use the old and single teaching methods when conducting teaching activities, which not only seriously affects students' enthusiasm for participating in dance classroom learning, but also impedes students' thinking consciousness and innovative ability. Therefore, teachers need to improve the teaching methods in accordance with the actual teaching, through the analysis of the value of folk dances, and the introduction of folk customs, religious beliefs, national stories and national music, so that students can be more enthusiastic in the learning environment In the atmosphere, fully enjoy the fun of learning dance knowledge, in the process of mobilizing the enthusiasm of learning, not only to ensure the improvement of learning quality, but also in the process of tapping the unique cultural value of folk dance, it will achieve comprehensive development.

\subsection{Mining the value of dance culture}

As an important manifestation of national culture, folk dance is not only an inheritance of national culture, but also a better development while understanding the cultural value it presents. Therefore, when conducting teaching activities, teachers can't blindly focus on teaching students' dancing skills and basic knowledge. They also need to guide students through the divergence of thinking consciousness, and they can focus on the cultural values presented in folk dances. Dig. This can not only effectively increase the students' emotional expression ability, but also introduce their emotions into the process of participating in the performance, and then perform a more vital dance.

\section{Conclusion}

Our country's cultural and artistic content covers a very wide range. National folk dance, as an important content, is not only a concrete manifestation of the national spirit, but also an important means of inheriting excellent culture. Therefore, teachers of colleges and universities need to pay close attention to the learning needs of college students when conducting national folk dance classroom teaching activities, and improve the teaching activities in a targeted manner, so as to mobilize students' enthusiasm to participate in classroom knowledge learning through the establishment of high-quality dance classrooms In the process of feeling the national culture, maintaining national unity, and inheriting 
the national spirit, it has grown into a high-quality dance talent in line with the core values of socialism.

\section{References}

1. Zhao Songshan. Research on the teaching of folk dances in colleges and universities_— Taking the undergraduate teaching of dance performance in the Art College of Yanbian University as an example[J]. Contemporary Music, 2020(02):124-126.

2. Plain. Thoughts on the promotion of local folk dance development by college dance education in ethnic minority areas___ Taking Jilin Art Institute dance teaching as an example[J]. Arts Education, 2017(23):83-84.

3. Liu Sui. Reflections on the promotion of local folk dance by college dance education in ethnic minority areasTaking dance teaching in Honghe College of Yunnan as an example[J]. Voice of the Yellow River, 2012(10): 65-67. 